\title{
Evaluation of Nitrogen Oxides Pollution in Takamatsu and Utazu Area in Kagawa Prefecture, Japan
}

\author{
Shoko Murakami ${ }^{1}$, Noriko Sakano ${ }^{1}$, Shigeru Suna ${ }^{2}$, Fumiyuki Asakawa ${ }^{3}$, Nobuyuki Miyatake ${ }^{1}$ \\ ${ }^{1}$ Department of Hygiene, Faculty of Medicine, Kagawa University, Miki, Kagawa, Japan; ${ }^{2}$ Kagawa Prefectural College of Health \\ Sciences, Kagawa, Japan; ${ }^{3}$ Kurashiki University of Science the Arts, Kurashiki, Japan. \\ Email: shoko@med.kagawa-u.ac.jp
}

Received December 21 $1^{\text {st }}$, 2010; revised February $6^{\text {th }}$, 2011; accepted March $12^{\text {th }}, 2011$.

\begin{abstract}
We evaluate nitrogen oxides pollution in Takamatsu and Utazu area in Kagawa prefecture, Japan. Annually observations for nitrogen oxides (nitrogen dioxide; $\mathrm{NO}_{2}$, nitric oxide; $\mathrm{NO}$ ) (1990-2007) were obtained from data base of Kagawa prefecture, Japan. Changes in $\mathrm{NO}_{2}$ and $\mathrm{NO}$ in Takamatsu and Utazu area were evaluated and compared. In 2007, $\mathrm{NO}_{2}, \mathrm{NO}$ and $\mathrm{NO}_{2}+\mathrm{NO}(\mathrm{ppm})$ in Takamatsu area were higher than those in Utazu area. However, $\mathrm{NO}_{2} /\left(\mathrm{NO}+\mathrm{NO}_{2}\right)$ in Takamatsu area was lower than that in Utazu area. From 1990 to 2007, mean of $\mathrm{NO}_{2}$ in a day over the level of 0.06 ppm was 30 days in Takamatsu area and only one day in Utazu area. Mean of $\mathrm{NO}_{2}$, $\mathrm{NO}$ and $\mathrm{NO}_{2}+\mathrm{NO}$ was significantly higher and $\mathrm{NO}_{2} /\left(\mathrm{NO}+\mathrm{NO}_{2}\right)$ was lower in Takamatsu area than that in Utazu area. In addition, $\mathrm{NO}_{2}, \mathrm{NO}$ and $\mathrm{NO}_{2}+\mathrm{NO}$ were negatively correlated and $\mathrm{NO}_{2} /\left(\mathrm{NO}+\mathrm{NO}_{2}\right)$ was positively correlated with years $(1990-2007)$ in $\mathrm{Ta}$ kamatsu area. The level of nitrogen oxides pollution in Utazu area was lower than Takamatsu area. Further observation is required for preventing nitrogen oxides pollution in Kagawa prefecture, Japan.
\end{abstract}

Keywords: Nitrogen Oxides, $\mathrm{NO}_{2}$, $\mathrm{NO}$, Utazu Area, Takamatsu Area

\section{Introduction}

Air pollution is one of the public health challenges in Japan. Air pollution occurs where the natural composition of the atmosphere is altered significantly in a way that is perceived as being harmful. In Japan, environmental air quality has changed remarkably since the 1960s. A serious environmental pollution problem caused by the enormous emission of pollutants from industries has been improved and controlled. Recently, another type of air pollution related to automobile exhaust in large cities has become a great problem.

Atmospheric Environmental Regional Observation System [1] in Ministry of the Environment monitor air pollutants, and their concentrations have not sufficiently achieved Japanese Environmental Quality Standards (JEQS) [2]. In Kagawa prefecture, Japan, air pollution has been also observed in some observation points [3].

However, the changes in nitrogen oxides such as nitrogen dioxide $\left(\mathrm{NO}_{2}\right)$, nitric oxide (NO), $\mathrm{NO}_{2}+\mathrm{NO}$ and $\mathrm{NO}_{2} /\left(\mathrm{NO}+\mathrm{NO}_{2}\right)$ in Kagawa prefecture, Japan still remains to be investigated, although Takamatsu is a main city located on north side of Shikoku and Utazu is a rural town in Kagawa prefecture of Shikoku Island, which sites are both located around the Inland Sea, Japan. Therefore, we evaluate the detailed changes in nitrogen oxides pollution in Takamatsu and Utazu area in Kagawa prefecture, Japan and compared each other.

\section{Methods}

\subsection{Study Area}

Takamatsu area, Kagawa prefecture, Japan, which includes Takamatsu city, is on the northern shore of Shikoku Island (in a temperate zone area). The population of 420000 people is situated on the Takamatsu area. Currently several public offices of Shikoku district are located in Takamatsu city. Although the surrounds of Takamatsu had been used primarily as paddy fields for agriculture, recently they have undergone rapid changes, developing into residential and/or commercial areas (Figure 1).

Utazu area, Kagawa prefecture, Japan, which includes Utazu-cho, is also on the northern shore, west from Ta- 
kamatsu area of Shikoku Island [4]. The population of 18,000 people is situated on the Utazu area. Utazu area had been used primarily as paddy fields for agriculture compared to Takamatsu area (Figure 1). Both observation sites are located around the Inland Sea, Japan.

\subsection{Data of Nitrogen Oxides}

Data of nitrogen oxides pollution in Takamatsu and Utazu areas in Japan for the required periods (1990-2007) were obtained from Data base of Kagawa prefecture, Japan [5]. $\mathrm{NO}_{2}$ (ppm), $\mathrm{NO}$ (ppm), $\mathrm{NO}_{2}+\mathrm{NO}$ (ppm) and $\mathrm{NO}_{2} /\left(\mathrm{NO}+\mathrm{NO}_{2}\right)(\%)$ were used for analysis. In general, toxicity of $\mathrm{NO}_{2}$ is higher than that of $\mathrm{NO}$ in plants [6], Therefore, we evaluate $\mathrm{NO}_{2} /\left(\mathrm{NO}+\mathrm{NO}_{2}\right)(\%)$ were also used for analysis.

\subsection{Statistical Analysis}

Data are expressed as means \pm standard deviation (S.D.) values. A comparison of parameters between the 2 groups was made using an unpaired $t$-test. Simple correlation analysis was performed as well to test for the significance of the linear relationship among continuous variables, $p<0.05$ was considered to indicate statistical significance.

\section{Results}

$\mathrm{NO}_{2}, \mathrm{NO}, \mathrm{NO}_{2}+\mathrm{NO}$ and $\mathrm{NO}_{2} /\left(\mathrm{NO}+\mathrm{NO}_{2}\right)$ in Takamatsu and Utazu area in 2007 are summarized in Table 1. $\mathrm{NO}_{2}$, $\mathrm{NO}$ and $\mathrm{NO}_{2}+\mathrm{NO}$ in Takamatsu area were higher than those in Utazu area. However, $\mathrm{NO}_{2} /\left(\mathrm{NO}+\mathrm{NO}_{2}\right)$ Takamatsu area was lower than that in Utazu area.

From 1990 to 2007, we compared the nitrogen oxides between Takamatsu and Utazu area (Table 2). Mean of $\mathrm{NO}_{2}$ in a day over the level of 0.06 ppm was 30 days in Takamatsu area and only one day in Utazu area during

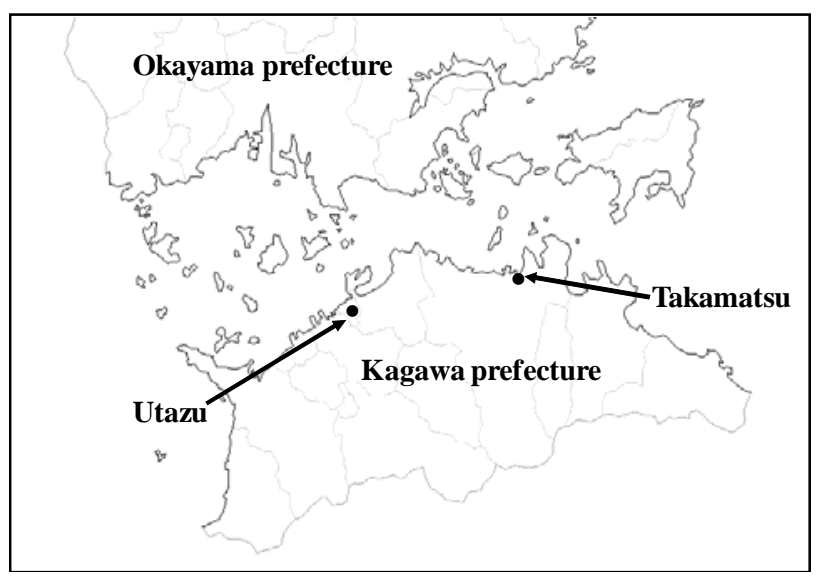

Figure 1. Study point of Takamatsu and Utazu, Kagawa prefecture, Japan (http://www.craftmap.box-i.net/map.php, accessed on Aug 27, 2010).
Table 1. Concentration or percentage of nitrogen oxides in Takamatsu and Utazu area in 2007.

\begin{tabular}{lcc}
\hline & Takamatsu area & Utazu area \\
\hline Mean of $\mathrm{NO}_{2}(\mathrm{ppm})$ & 0.019 & 0.017 \\
Mean of $\mathrm{NO}(\mathrm{ppm})$ & 0.010 & 0.007 \\
Mean of $\mathrm{NO}_{2}+\mathrm{NO}(\mathrm{ppm})$ & 0.029 & 0.024 \\
$\mathrm{NO}_{2} /\left(\mathrm{NO}+\mathrm{NO}_{2}\right)(\%)$ & 65.1 & 69.8 \\
\hline
\end{tabular}

observation period (1990-2007). Mean values of $\mathrm{NO}_{2}$, $\mathrm{NO}$ and $\mathrm{NO}_{2}+\mathrm{NO}$ in Takamatsu area were significantly higher than those in Utazu area. However, mean value of $\mathrm{NO}_{2} /\left(\mathrm{NO}+\mathrm{NO}_{2}\right)$ in Takamatsu area was lower than that in Utazu area as showed in 2007.

We further analyzed the relationship between nitrogen oxides and years in Takamatsu and Utazu areas. $\mathrm{NO}_{2}$, $\mathrm{NO}$ and $\mathrm{NO}_{2}+\mathrm{NO}$ were negatively correlated with years in Takamatsu area. $\mathrm{NO}_{2} /\left(\mathrm{NO}+\mathrm{NO}_{2}\right)$ was positively corre- lated with years in Takamatsu area (Table 3, Figure 2). In Utazu area, parameters of nitrogen oxides were not significantly correlated with years.

\section{Discussion}

We firstly evaluated and compared nitrogen oxides pollution in Takamatsu and Utazu area, Kagawa prefecture, Japan, which located around the Inland Sea, Japan. $\mathrm{NO}_{2}$, $\mathrm{NO}$ and $\mathrm{NO}_{2}+\mathrm{NO}$ in Takamatsu area were higher than in Utazu area. However, $\mathrm{NO}_{2}$, $\mathrm{NO}$ and $\mathrm{NO}_{2}+\mathrm{NO}$ in Takamatsu area were significantly improved these years.

JEQS [2] of $\mathrm{NO}_{2}$ were recommended that mean value of $\mathrm{NO}_{2}$ in a day was under the level of $0.06 \mathrm{ppm}$ and $\mathrm{NO}_{2}$ value in Japan were almost under the level of $0.06 \mathrm{ppm}$ [7]. Ono et al. reported that they surveyed the characterization of residential suspended particulate matter (SPM) and $\mathrm{NO}_{2}$ concentrations along the major road ways in Tokyo [8]. The prevalence rate of respiratory symptoms was higher in those areas nearest roadways with heavy traffic both in children and adults [1]. Yorifuji et al. reported that long term exposure to traffic-related air pollution, indexed by $\mathrm{NO}_{2}$ concentration, increases the risk of cardiopulmonary mortality, even in a population with a relatively low BMI and increases the risk of lung cancer mortality in non-smokers [9]. Piver et $a l$. also reported that same-day daily maximum temperature and daily average concentrations of $\mathrm{NO}_{2}$ were the most significant risk factors for heat stroke in all age groups of males and females [10]. Rosenlund et al. showed that long-term air pollution exposure increases the risk of coronary heart disease during the period 1998 - 2000 [11]. In addition, Yamazaki et al [12] showed that they evaluated the relationship between nitrogen oxides and health-related quality of life (HRQOL) by using Medical Outcomes Study Short From-36 Health Survey 
Table 2. Comparison of nitrogen oxides from 1990 to 2007 in Takamatsu and Utazu area, Japan.

\begin{tabular}{lccccccc}
\hline & \multicolumn{3}{c}{ Takamatsu area } & \multicolumn{3}{c}{ Utazu area } & $p$ \\
\cline { 2 - 6 } & Mean \pm S.D. & Max. & Min. & Mean \pm S.D. & Max. & Min & \\
\hline $\mathrm{NO}_{2}(\mathrm{ppm})$ & $0.025 \pm 0.003$ & 0.030 & 0.019 & $0.019 \pm 0.002$ & 0.023 & 0.016 & $<0.0001$ \\
$\mathrm{NO}(\mathrm{ppm})$ & $0.021 \pm 0.006$ & 0.030 & 0.031 & $0.010 \pm 0.002$ & 0.014 & 0.007 & $<0.0001$ \\
$\mathrm{NO}_{2}+\mathrm{NO}(\mathrm{ppm})$ & $0.046 \pm 0.009$ & 0.061 & 0.029 & $0.029 \pm 0.004$ & 0.038 & 0.022 & $<0.0001$ \\
$\mathrm{NO}_{2} /\left(\mathrm{NO}+\mathrm{NO}_{2}\right)(\%)$ & $54.9 \pm 4.6$ & 65.1 & 48.6 & $65.1 \pm 2.6$ & 69.9 & 60.2 & $<0.0001$ \\
\hline
\end{tabular}

$p$ : Takamatsu area vs. Utazu area (unpaired $t$-test)

Table 3. Relationship between nitrogen oxides and years (1990-2007) in Takamatsu and Utazu area, Japan.

\begin{tabular}{lcccc}
\hline & \multicolumn{2}{c}{ Takamatsu area } & \multicolumn{2}{c}{ Utazu area } \\
\cline { 2 - 4 } & $\mathrm{r}$ & $p$ & $\mathrm{r}$ & 0.714 \\
\hline Mean of $\mathrm{NO}_{2}$ in a year $(\mathrm{ppm})$ & -0.548 & 0.019 & -0.093 & -0.335 \\
Mean of $\mathrm{NO}$ in a year $(\mathrm{ppm})$ & -0.580 & 0.012 & -0.200 & 0.175 \\
Mean of $\mathrm{NO}_{2}+\mathrm{NO}$ in a year $(\mathrm{ppm})$ & -0.565 & 0.015 & 0.376 \\
$\mathrm{NO}_{2} /\left(\mathrm{NO}+\mathrm{NO}_{2}\right)(\%)$ & 0.589 & 0.010 & 0.124 \\
\hline
\end{tabular}
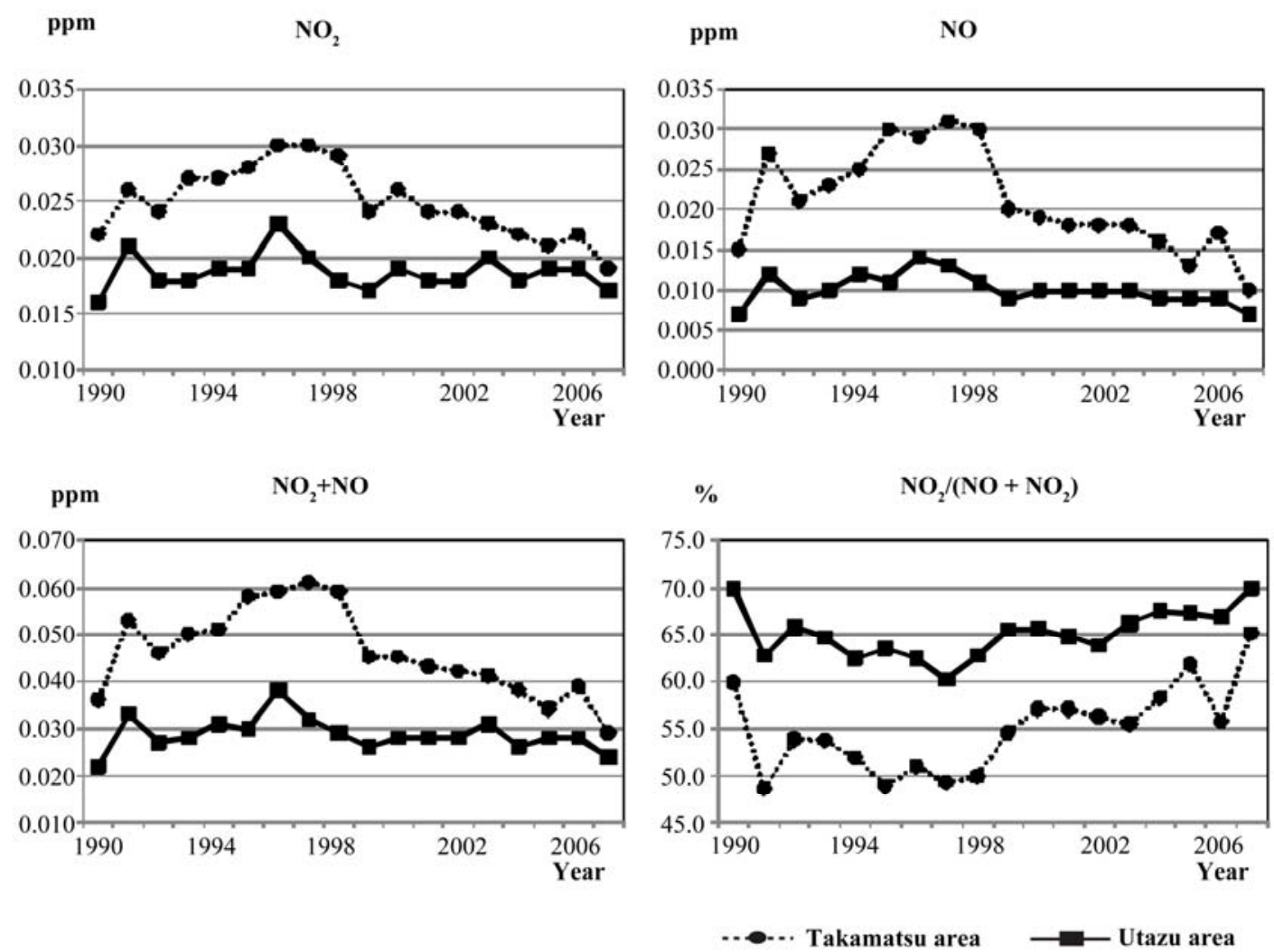

Figure 2. Changes in parameters of nitrogen oxides from 1990 to 2007 in Takamatsu and Utazu areas in Kagawa prefecture, Japan.

(SF-36) [13]. They observed a significant linear trend of a lower 'vitality' domain score in the SF-36 in groups exposed to higher concentrations of nitrogen oxides [12]. In this study, we evaluated the parameters of nitrogen oxides in Takamatsu and Utazu area in Kagawa prefecture, Japan. Over the level of 0.06 ppm in $\mathrm{NO}_{2}$ was 30 days in Takamatsu area and only one day in Utazu area during observation period (1990 - 2007). In addition, 
$\mathrm{NO}_{2}$, $\mathrm{NO}$ and $\mathrm{NO}_{2}+\mathrm{NO}$ in Takamatsu area were significantly improved.

Potential limitations still remain in this study. First, we could not prove the link between nitrogen oxides and health status i.e. cardiopulmonary diseases, mortality rate and HROQL as previous studies. Second, although Ramadan reported that the NO distribution was similar to that of $\mathrm{NO}_{2}$ [14], $\mathrm{NO}_{2} /\left(\mathrm{NO}+\mathrm{NO}_{2}\right)$ in Takamatsu area was positively correlated with years. In general, toxicity of $\mathrm{NO}_{2}$ is higher than that of $\mathrm{NO}$ in plants [6]. Hiragushi et al have studied the relation between diabetic glomerular hyperfiltration and the NO system. And they found that the urinary $\mathrm{NO}_{\mathrm{x}}\left(\mathrm{NO}_{2}^{-}\right.$and $\left.\mathrm{NO}_{3}^{-}\right)$was significantly higher in normoalbumiuric in patients with type 2 diabetes mellitus compared with normal subjects [15]. In addition, NO, known as endothelium derived relaxing factor, is involved in glomerular hyperfiltration of experimental diabetic rats [16]. Taylor et al. reported that two significant cases that illustrate the probable cause and the treatment strategies for delivery of high concentrations of NO, resulting in methemoglobinemia with moderate and even low-dose delivered NO [17]. We could not prove the mechanism and issues of an increase in $\mathrm{NO}_{2} /(\mathrm{NO}+$ $\mathrm{NO}_{2}$ ) in Takamatsu area, Kagawa prefecture, Japan. Therefore, monitoring of nitrogen oxides pollution are further required for preventing air pollution-related diseases in Kagawa prefecture, Japan.

\section{REFERENCES}

[1] “Atmospheric Environmental Regional Observation System”, 2010. http://soramame.taiki.go.jp/

[2] “Japanese Environmental Quality Standards (JEQS)”, 2010. http://www.env.go.jp/kijun/taiki.html

[3] "Air pollution has Been Also Observed in Some Observation Points in Kagawa Prefecture, Japan”, 2010. http://www.taiki.pref.kagawa.jp/TAIKI/KANKYO/gaiyo. php.

[4] “Utazu cho, Kagawa prefecture, Japan”, 2010. http://town.utazu.kagawa.jp/2kanko_index.html.

[5] "Data of Air Pollution By Using Nitrogen Oxides in Takamatsu and Utazu Areas in Japan”, 2010. http://www.taiki.pref.kagawa.jp/TAIKI/KANKYO/downl oad.php.

[6] K. Shimazaki, S. W. Yu, T. Sakaki and K. Tanaka, "Differences between Spinach and Kidney Bean Plants in Terms of Sensitivity to Fumigation with $\mathrm{NO}_{2}$," Plant Cell Physiology, Vol. 33, No. 3, 1992, pp. 267-273.

[7] “Ministry of the Environmental, Japan”, 2010. http://ww w.env.go.jp/policy/hakusyo/h21/pdf/2-2.pdf.

[8] M. Ono, M. Murakami, H. Nitta, S. Nakai and K. Maeda, "Epidemiological Studies of Air Pollution and Health Effects in Areas near Roadways with Heavy Traffic in To- kyo,” Nippon Koshu Eisei Zasshi, Vol. 37, No. 5, 1990, pp. 321-332.

[9] T. Yorifuji, S. Kashima, T. Tsuda, S. Takao, E. Suzuki, H. Doi, M. Sugiyama, K. Ishikawa-Takata and T. Ohta, "Long-Term Exposure to Traffic-Related Air Pollution and Mortality in Shizuoka, Japan,” Occupational and Environmental Medicine, Vol. 67, No. 2, 2010, pp. 111-117. doi:10.1136/oem.2008.045542

[10] W. T. Piver, M. Ando, F. Ye and C. J. Portier, "Temperature and Air Pollution as Risk Factors for Heat Stroke in Tokyo, July and August 1980-1995,” Environmental Health Perspective, Vol. 107, No. 11, 1999, pp. 911-916. doi:10.1289/ehp.99107911

[11] M. Rosenlund, S. Picciotto, F. Forastiere, M. Stafoggia and C. A. Perucci, "Traffic-Related Air Pollution in Relation to Incidence and Prognosis of Coronary Heart Disease,” Epidemiology, Vol. 19, No. 1, 2008, pp. 121-128. doi:10.1097/EDE.0b013e31815c1921

[12] S. Yamazaki, H. Nitta, Y. Murakami and S. Fukuhara, "Association between Ambient Air Pollution and Health-Related Quality of Life in Japan: Ecological Study," International Journal of Environmental Health Research, Vol. 15, No. 5, 2005, pp. 383-391. doi:10.1080/09603120500292279

[13] C. A. McHorney, J. E. Jr Ware and A. E. Raczek, "The MOS 36-Item Short-Form Health Survey (SF-36): II. Psychometric and Clinical Tests of Validity in Measuring Physical and Mental Health Constructs," Medical Care, Vol. 31, No. 3, 1993, pp. 247-263. doi:10.1097/00005650-199303000-00006

[14] A. A. Ramadan, "Air Quality Assessment in Southern Kuwait Using Diffusive Passive Samplers,” Environ Monit Assess, Vol. 160, No. 1-4, 2010, pp. 413-423. doi:10.1007/s10661-008-0705-8

[15] K. Hiragushi, H. Sugimoto, K. Shikata, T. Yamashita, N. Miyatake, Y. Shikata, J. Wada, I. Kumagai, M. Fukushima and H. Makino, "Nitric Oxide System Is Involved in Glomerular Hyperfiltration in Japanese Normo- And Micro-Albuminuric Patients with Type 2 Diabetes," Diabetes Research and Clinical Practice, Vol. 53, No. 3, 2001, pp. 149-159. doi:10.1016/S0168-8227(01)00260-1

[16] H. Sugimoto, K. Shikata, M. Matsuda, M. Kushiro, Y. Hayashi, K. Hiragushi, J. Wada and H. Makino, "Increased Expression of Endothelial Cell Nitric Oxide Synthase (ecNOS) in Afferent and Glomerular Endothelial Cells Is Involved in Glomerular Hyperfiltration of Diabetic Nephropathy,” Diabetologia, Vol. 41, No. 12, 1998, pp. 1426-1434. doi:10.1007/s001250051088

[17] M. B. Taylor, K. G. Christian, N. Patel and K. B. Churchwell, "Methemoglobinemia: Toxicity of Inhaled Nitric Oxide Therapy," Pediatric Critical Care Medicine, Vol. 2, No. 1, 2001, pp. 99-101. doi:10.1097/00130478-200101000-00019 